\section{Assessing Tolerance to Sodium Chloride Salinity in Fourteen Floriculture Species}

\author{
Gonzalo H. Villarino ${ }^{1}$ and Neil S. Mattson
}

AdDitional INDEX wORDs. salt stress, osmotic stress, bedding plants, Petunia $\times$ bybrida, $\mathrm{NaCl}$, saline irrigation

SUMMARY. The use of saline irrigation water may be inevitable in the future since the freshwater supply is decreasing over time. In some regions of the United States, producers of both ornamental and agronomic crops are already facing a limited supply of high-quality water. Therefore, it is necessary to determine the salt tolerance of commonly used greenhouse bedding plants to minimize potential salt damage before use of nonpotable water sources is mandated. Research screening several bedding plants has not taken place for more than two decades. Therefore, we undertook experiments to screen popular bedding plants for salt tolerance during greenhouse production. Transplants were exposed to 0 (control), 20, 40, 60, or 80 $\mathrm{mm}$ sodium chloride $(\mathrm{NaCl})$ in the irrigation water for 5 weeks resulting in average substrate pour-thru electrical conductivity (EC) values of 4.0 (control), 7.0, 9.8, 12.1, or $14.2 \mathrm{dS} \cdot \mathrm{m}^{-1}$, respectively. Pansy (Viola tricolor) and zinnia (Zinnia angustifolia), the most sensitive species examined, exhibited $100 \%$ mortality when exposed to an EC of $14.2 \mathrm{dS} \cdot \mathrm{m}^{-1}$. The least affected species for dry weight (DW) was snapdragon (Antirrbinum majus) with a 54\% reduction as EC increased from 4.0 to $14.2 \mathrm{dS} \cdot \mathrm{m}^{-1}$. Only fuchsia (Fuchsia bybrida) and snapdragon were unaffected by an EC of $7.0 \mathrm{dS} \cdot \mathrm{m}^{-1}$, whereas at $9.8 \mathrm{dS} \cdot \mathrm{m}^{-1}$ all of the species had a significantly reduced DW as compared with control plants. Verbena (Verbena $\times$ bybrida), petunia (Petunia $\times$ bybrida), coleus (Solenostemon scutellarioides), and begonia (Begonia hiemalis) were the only species that did not undergo a significant height reduction in comparing $9.8 \mathrm{dS} \cdot \mathrm{m}^{-1}$ to control. A classification of the 14 species is created here on the basis of plant DW to provide guidance as to which species could be irrigated with more saline water while not compromising plant growth and quality.

$\mathrm{W}$ ater quality and conservation are at the forefront of public environmental concerns; hence, greenhouse operations particularly in Europe, Israel, and California are reorganizing and investing in their irrigation practices (Morgan and Reed, 1998). As supply of high-quality water decreases growers are being forced to irrigate their crops with poor-quality water and/or saline water (Lieth and Burger, 1989). Use of recycled water to irrigate floriculture bedding plants may be warranted in the future because of declining freshwater supply and increasing human population (Niu and Rodriguez, 2006). In regions lacking outlets for agricultural drainage disposal or where water supply is scarce, the recycling of drainage waters for irrigation increasingly is seen as a viable management option (Skaggs et al., 2006).

Treated municipal effluent has been used for irrigation of golf courses and some horticulture crops, particularly citrus (Citrus spp.) orchards, in

Department of Horticulture, Cornell University, Ithaca, NY 14853

${ }^{1}$ Corresponding author. E-mail: ghv8@cornell.edu. many areas of the United States (Niu and Rodriguez, 2006). For example, in Florida 92,345 ha of land was irrigated with reclaimed municipal water in $2005 ; 6144$ ha was agricultural land and the rest was used for irrigating golf courses and landscapes (Morgan et al., 2008).

Besides reclaimed municipal water, there are additional sources of salt in irrigation water. Road deicing salts in northern locations can salinize irrigation water (Lerner, 2006) hampering plant production. Intrusion of seawater into underground aquifers is also a severe problem in some coastal areas (Lerner, 2006). The need to develop new, innovative, and more efficient agricultural water management systems is essential to developing sustainable irrigation (Skaggs et al., 2006).

To our knowledge, floriculture breeding programs are not actively selecting new cultivars for salt tolerance; however, biotechnology approaches have been increasingly investigated (Xu et al., 2009).

As a result of the current and increasing use of saline irrigation water, it is imperative for the floriculture industry to determine the salt tolerance of commonly used greenhouse bedding plants to minimize potential salt damage before the use of nonpotable water sources are mandated. Such research has been conducted for five herbaceous perennials grown in the landscape in the arid and semiarid southwestern United States (Niu and Rodriguez, 2006). To our knowledge, the last significant screening of herbaceous annuals (bedding plants) took place over two decades ago (Tija and Rose, 1987). Clearly, plant materials have changed greatly over the intervening years justifying another look at salt tolerance in bedding plants.

In this work, we characterized the response during greenhouse production of 14 popular floriculture species exposed to different levels of $\mathrm{NaCl}$ salinity in the irrigation water. We aim to find clusters of plants that respond similarly to elevated salts so that we may classify species on the basis of how sensitive they are for practical management guidelines.

\section{Materials and methods}

Plant material and treatMENTS. A greenhouse experiment was conducted at Cornell University, Ithaca, $\mathrm{NY}$ (lat. $42.4^{\circ} \mathrm{N}$ ) from 11 Feb. to 15 Apr. 2010. Fourteen floriculture species were used for the experiment: 'Florini Amalia Yellow' snapdragon, 'Solenia Light Pink' rieger begonia, 'Mediterranian Polka Dot' vinca (Catharanthus roseus), 'White Manaus' euphorbia (Euphorbia hybrid), 'Trailing Dark Eyes'

\begin{tabular}{llll}
\hline $\begin{array}{l}\text { Units } \\
\text { To convert U.S. to SI, } \\
\text { multiply by }\end{array}$ & U.S. unit & SI unit & $\begin{array}{l}\text { To convert SI to U.S., } \\
\text { multiply by }\end{array}$ \\
\hline 0.4047 & acre $(\mathrm{s})$ & $\mathrm{ha}$ & 2.4711 \\
0.3048 & $\mathrm{ft}$ & $\mathrm{m}$ & 3.2808 \\
3.7854 & gal & $\mathrm{L}$ & 0.2642 \\
2.54 & inch(es) & $\mathrm{cm}$ & 0.3937 \\
1 & $\mathrm{mmho} / \mathrm{cm}$ & $\mathrm{dS} \cdot \mathrm{m}^{-1}$ & 1 \\
28.3495 & $\mathrm{Oz}$ & $\mathrm{g}$ & 0.0353 \\
1 & $\mathrm{ppm}$ & $\mathrm{mg} \cdot \mathrm{L}^{-1}$ & 1 \\
$\left({ }^{\circ} \mathrm{F}-32\right) \div 1.8$ & ${ }^{\circ} \mathrm{F}$ & ${ }^{\circ} \mathrm{C}$ & $\left(1.8 \times{ }^{\circ} \mathrm{C}\right)+32$ \\
& & &
\end{tabular}


fuchsia, 'Super Elfin XP White' impatiens (Impatiens walleriana), 'Classic Scarlet' zonal geranium (Pelargonium $\times$ hortorum), 'Ramblin White' petunia, 'Vista Red' salvia (Salvia splendens), 'Stained Glassworks Copper' coleus, 'Lanai Dark Red' verbena, 'Delta Blue Blotch' pansy, 'Crested Bonanza Bolero' french marigold (Tagetes patula), and 'Star Gold' zinnia 'Star Gold'.

Plug/liner trays were received from a commercial propagator (C. Raker and Sons, Litchfield, MI) and were held in trays for 2 weeks in the greenhouse while being watered with municipal tap water along with $20 \mathrm{~N}-$ $2.2 \mathrm{P}-16.6 \mathrm{~K}$ water-soluble fertilizer at $150 \mathrm{mg} \cdot \mathrm{L}^{-1}$ nitrogen (Jack's Professional LXTM 21-5-20; J.R. Peter's, Allentown, PA).

A total of 350 plants ( 14 species $\times$ 5 treatments $\times 5$ replicates) were transplanted into $10-\mathrm{cm}$ pots containing a soil-less substrate (Metromix 280; Sun Gro Horticulture, Vancouver, British Columbia, Canada). Plants were irrigated daily by manually turning on a drip irrigation system until water just began to leach out of the bottom of containers (i.e., leaching fraction about $5 \%$ ). At each irrigation event, plants received the same commercial fertilizer prepared as described above.

One week after transplanting, the salt treatments were commenced. The five salt treatments were prepared in 140-gal tanks, $\mathrm{NaCl}$ was added so as to achieve 0 (control), 20, 40, 60, and 80 $\mathrm{mm} \mathrm{NaCl}$. The tanks contained $\mathrm{NaCl}$ as well as the commercial fertilizer (as described above) so that plants received both fertilizer and $\mathrm{NaCl}$ in their irrigation water. Treatments were randomly divided so that each bench (14X $5 \mathrm{ft}$ ) contained a reservoir with one salinity treatment. Within each treatment, five plants were randomly sampled each week for EC and $\mathrm{pH}$ measurements. These were measured using an EC meter (Oakton Instruments, Vernon Hills, IL) and $\mathrm{pH}$ meter (pHTestr 20 , Oakton Instruments), using the pour-thru method following the protocol of Cavins et al. (2000). Plants received salt treatments for 5 weeks, averaged across the treatment period the pour-thru EC values of the five treatments were 4.0 (control), 7.0, 9.8, 12.1, or $14.2 \mathrm{dS} \cdot \mathrm{m}^{-1}$.

Six weeks after transplanting (5 weeks after salt treatments commenced) final pour-thru $\mathrm{pH} / \mathrm{EC}$ data were recorded from each individual plant. Destructive harvest was used to obtain total shoot fresh weight $(\mathrm{FW})$. Total DW was recorded after plants were oven dried at $80^{\circ} \mathrm{C}$ for $4 \mathrm{~d}$. Plant height (from the soil interface to the tallest part of the plant) and plant width (average of two measurements-the widest part of the plant and width at $90^{\circ}$ from this location) were also recorded.

To be able to compare the salinity effects from one species to another, we compared the percent reduction in measured parameters as EC increased from 4.0 to $14.2 \mathrm{dS} \cdot \mathrm{m}^{-1}$. For a given species, percent DW reduction was calculated as: (average DW at $4.0 \mathrm{dS} \cdot \mathrm{m}^{-1}$ average DW at $\left.14.2 \mathrm{dS} \cdot \mathrm{m}^{-1}\right) \div$ average DW at $4.0 \mathrm{dS} \cdot \mathrm{m}^{-1}$.

EXPERIMENTAL DESIGN AND STATISTICAL ANALYSIS. This screening experiment was designed with unblocked treatments using repeated measures. Each bench had one of five $\mathrm{NaCl}$ treatments, 14 plant species were used with five repeated measures randomly arranged on a bench per species by treatment combination. Analysis of variance was used to determine significant $\mathrm{NaCl}$ treatment effects on the measured parameters (JMP Version 8; SAS Institute, Cary, NC). Where significant differences were found, Tukey's honestly significant difference test was used to determine mean separations within species across salt treatment.

\section{Results}

Although the control treatment $\left(4.0 \mathrm{dS} \cdot \mathrm{m}^{-1}\right)$ EC remained relatively stable throughout the experiment, EC increased across the weekly periods for the added salt treatments (Fig. 1), likely because of the low leaching fraction. Conversely, $\mathrm{pH}$ remained stable across the treatment period and averaged 6.0 (data not shown).

Plant FW, DW, width, and height were significantly reduced with exposure to increasing $\mathrm{NaCl}$ for all species. In terms of percentage DW decrease, the least affected species was snapdragon with a $54 \%$ reduction, and the most affected was salvia with $98 \%$ reduction as EC increased from 4.0 to 14.2 $\mathrm{d} S \cdot \mathrm{m}^{-1}$. Only the DW of fuchsia and snapdragon was not significantly reduced as $\mathrm{NaCl}$ increased from 4.0 to $7.0 \mathrm{dS} \cdot \mathrm{m}^{-1}$. While comparing control to $9.8 \mathrm{dS} \cdot \mathrm{m}^{-1}$ all of the species had a significantly reduced DW (Figs. 2-6). In terms of $\mathrm{DW}, 12.1 \mathrm{dS} \cdot \mathrm{m}^{-1}$ was detrimental to all species examined; interestingly only five species seemed to be further damaged when salt concentration was further increased to 14.2 $\mathrm{dS} \cdot \mathrm{m}^{-1}$ (Figs. 2-6), which may be because pour-thru EC values were fairly similar between these two treatments by the end of the experiment, indicating that the $14.2 \mathrm{dS} \cdot \mathrm{m}^{-1}$ treatment did not accumulate significantly greater salt than the $4.0 \mathrm{dS} \cdot \mathrm{m}^{-1}$ treatment. Zinnia stands out as an example of plants that can be damaged visually with exposure to even $7 \mathrm{dS} \cdot \mathrm{m}^{-1}$ as with this treatment all plants exhibited marginal necrosis on lower leaves.

For FW the least affected species were petunia and snapdragon, both exhibited a $52 \%$ reduction as $\mathrm{NaCl}$

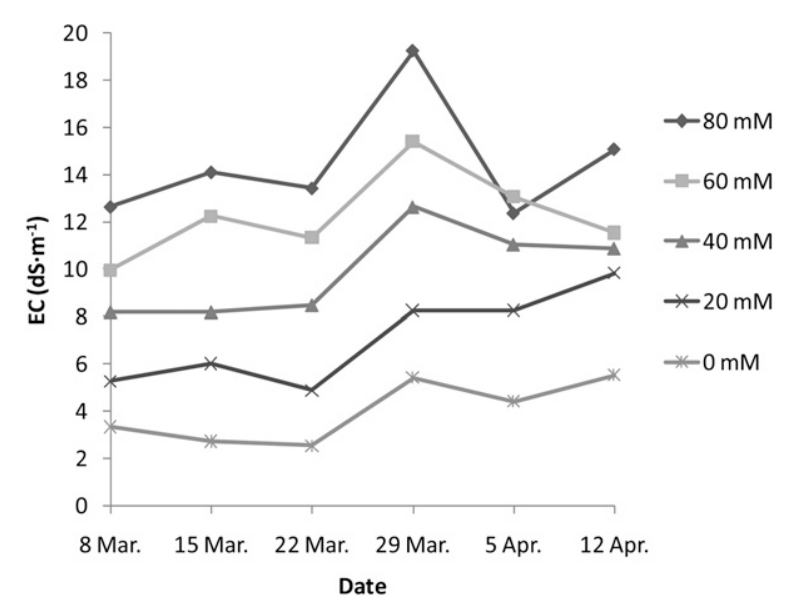

Fig. 1. The effect of increasing sodium chloride $(\mathrm{NaCl})$ concentration in irrigation water during a 5-week treatment period on substrate pour-thru electrical conductivity (EC). Data are means of five randomly selected plants per $\mathrm{NaCl}$ treatment; $1 \mathrm{dS} \cdot \mathrm{m}^{-1}=1 \mathrm{mmho} / \mathrm{cm}$. 

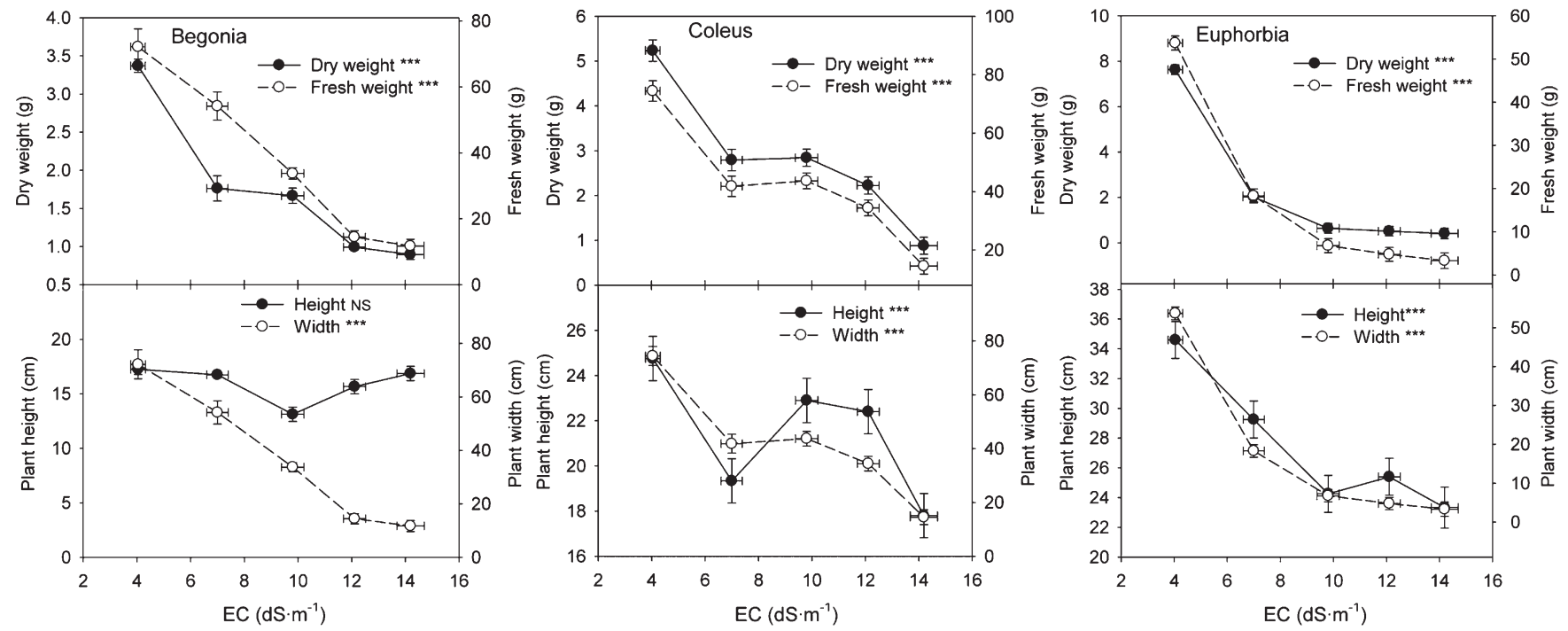

Fig. 2. Growth response of begonia, coleus, and euphorbia transplants to increasing root-zone salinity following a 5-week treatment period; $y$ data are means \pm SE of five plants; $x$ data are means \pm SE of weekly pour-thru electrical conductivity (EC) measurements; $1 \mathrm{dS} \cdot \mathrm{m}^{-1}=1 \mathrm{mmho} / \mathrm{cm}, 1 \mathrm{~g}=0.0353 \mathrm{oz}, 1 \mathrm{~cm}=0.3937$ inch; $\mathrm{NS},{ }^{*}, * *{ }^{*} * *$, nonsignificant or significant at $P \leq 0.05,0.01,0.001$, respectively.
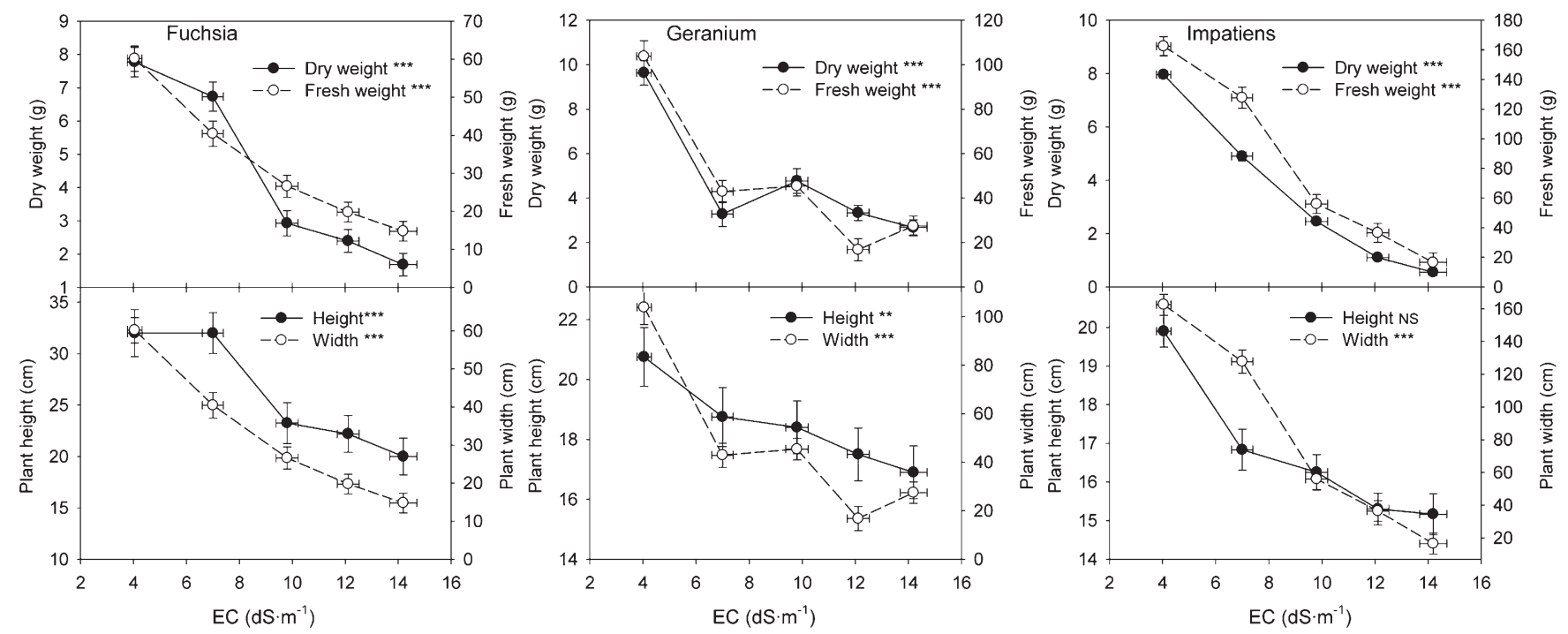

Fig. 3. Growth response of fuchsia, geranium, and impatiens transplants to increasing root-zone salinity following a 5-week treatment period; $y$ data are means \pm SE of five plants; $x$ data are means \pm SE of weekly pour-thru electrical conductivity (EC) measurements; $1 \mathrm{dS} \cdot \mathrm{m}^{-1}=1 \mathrm{mmho} / \mathrm{cm}, 1 \mathrm{~g}=0.0353 \mathrm{oz}, 1 \mathrm{~cm}=0.3937$ inch; $\mathrm{NS},{ }^{*},{ }^{*} *{ }^{*} * *$, nonsignificant or significant at $P \leq 0.05,0.01,0.001$, respectively.

increased from 4.0 to $14.2 \mathrm{dS} \cdot \mathrm{m}^{-1}$. Pansy and zinnia were the most sensitive species exhibiting $100 \%$ mortality at the highest $\mathrm{NaCl}$ treatment. Salvia was also very sensitive, FW was reduced by $96 \%$ as EC increased from 4.0 to $14.2 \mathrm{dS} \cdot \mathrm{m}^{-1}$. While comparing control to $9.8-\mathrm{dS} \cdot \mathrm{m}^{-1}$ treatment all of the species exhibited a significantly reduced FW (Figs. 2-6). Only coleus, pansy, verbena, and zinnia showed further damage when salt concentration increased from 12.1 to $14.2 \mathrm{dS} \cdot \mathrm{m}^{-1}$ (Figs. 2 and 4-6).
Overall, plant width was slightly less affected to increasing $\mathrm{NaCl}$ treatment than DW and FW parameters. Begonia, euphorbia, petunia, snapdragon, and verbena did not show a significant reduction of width when salt increased from 4.0 to $7.0 \mathrm{dS} \cdot \mathrm{m}^{-1}$, whereas both FW and DW of these species was significantly reduced when treatment increased from 4.0 to 7.0 $\mathrm{dS} \cdot \mathrm{m}^{-1}$ (Figs. 2-6). The least affected species was petunia with a reduction of $34 \%$ and the most affected was salvia with $92 \%$ as $\mathrm{NaCl}$ increased from 4.0 to $14.2 \mathrm{dS} \cdot \mathrm{m}^{-1}$. For all of the species (expect begonia), there was a significant reduction of width when comparing control to $9.8 \mathrm{dS} \cdot \mathrm{m}^{-1}$ of $\mathrm{NaCl}$. Further damage as $\mathrm{NaCl}$ increased from 12.1 to $14.2 \mathrm{dS} \cdot \mathrm{m}^{-1}$ was seen only in impatiens, pansy, salvia, zinnia, and verbena (Figs. 2-6).

Begonia was the least affected species for plant height; it was not significantly reduced as EC increased from 4.0 to $14.2 \mathrm{dS} \cdot \mathrm{m}^{-1}$ (Fig. 2). The most affected species was pansy with a $49 \%$ reduction as EC increased from 

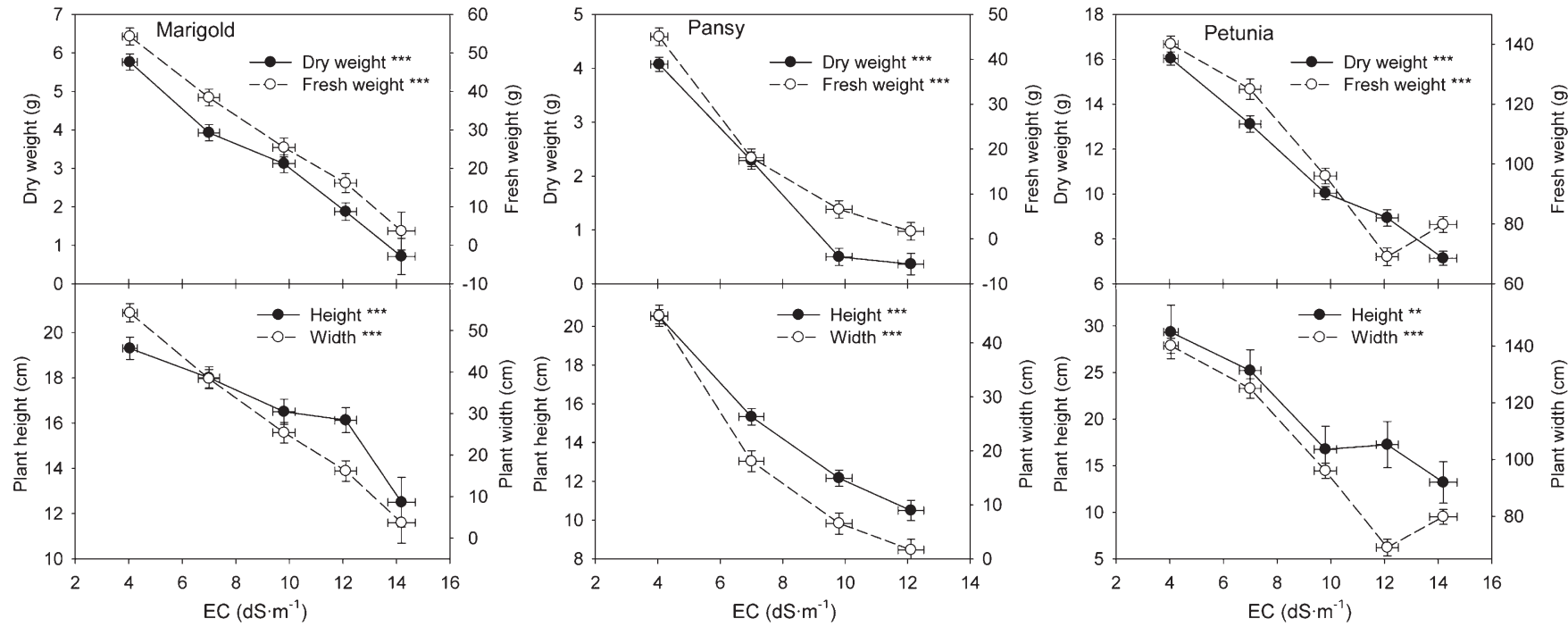

Fig. 4. Growth response of marigold, pansy, and petunia transplants to increasing root-zone salinity following a 5-week treatment period; $y$ data are means \pm SE of five plants; $x$ data are means \pm SE of weekly pour-thru electrical conductivity (EC) measurements; $1 \mathrm{dS} \cdot \mathrm{m}^{-1}=1 \mathrm{mmho} / \mathrm{cm}, 1 \mathrm{~g}=0.0353 \mathrm{oz}, 1 \mathrm{~cm}=0.3937 \mathrm{inch} ; \mathrm{NS},{ }^{*},{ }^{*}$ *, * * , nonsignificant or significant at $P \leq 0.05,0.01,0.001$, respectively.
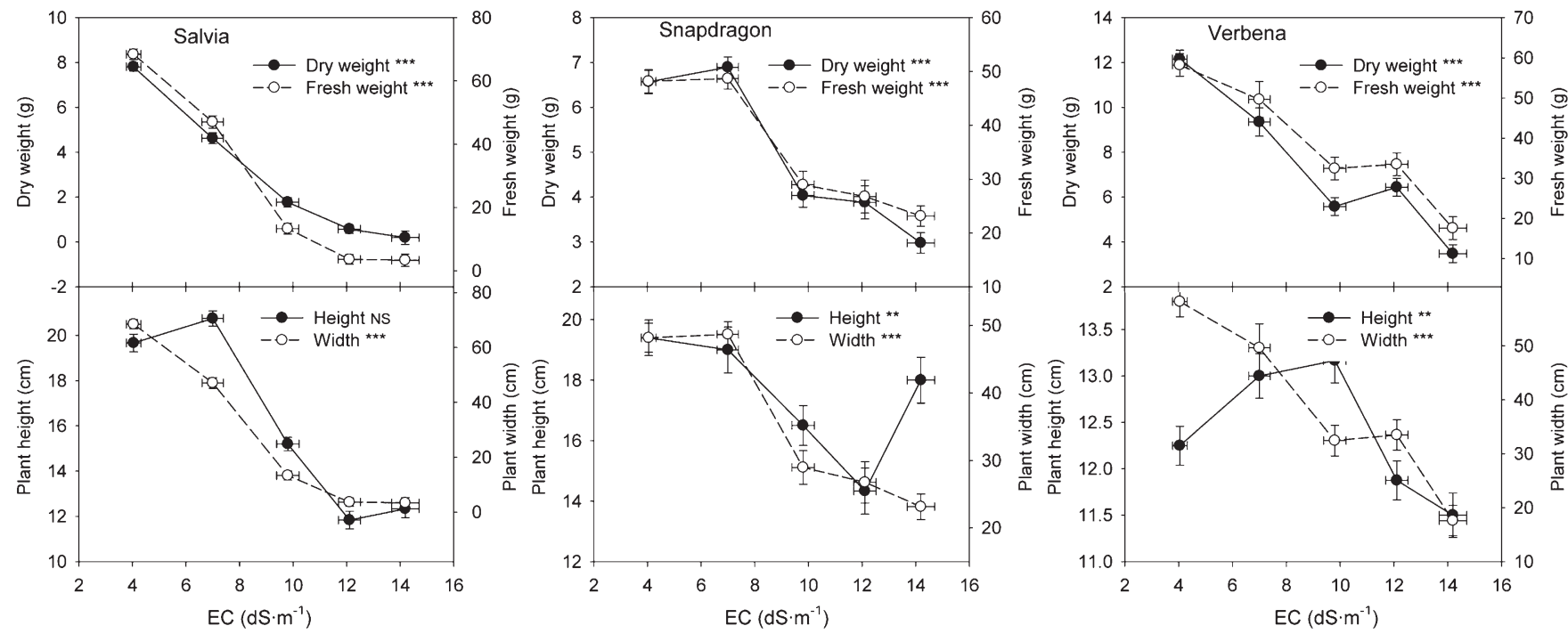

Fig. 5. Growth response of salvia, snapdragon, and verbena transplants to increasing root-zone salinity following a 5-week treatment period; $y$ data are means \pm SE of five plants; $x$ data are means \pm SE of weekly pour-thru electrical conductivity (EC) measurements; $1 \mathrm{dS} \cdot \mathrm{m}^{-1}=1 \mathrm{mmho} / \mathrm{cm}, 1 \mathrm{~g}=0.0353 \mathrm{oz}, 1 \mathrm{~cm}=0.3937 \mathrm{inch} ; \mathrm{NS},{ }^{*},{ }^{*}{ }^{*},{ }^{*} *$, nonsignificant or significant at $P \leq 0.05,0.01,0.001$, respectively.

4 to $12.1 \mathrm{dS} \cdot \mathrm{m}^{-1}$. Similar to plant width, not all the species showed a significant reduction in height as EC increased from 4.0 to $7 \mathrm{dS} \cdot \mathrm{m}^{-1}$. For begonia, fuchsia, marigold, petunia, snapdragon, verbena, and vinca there was not a significant reduction in height (whereas for both FW and DW, there was significant reduction when treatment increased from 4.0 to 7 $\left.\mathrm{dS} \cdot \mathrm{m}^{-1} \mathrm{EC}\right)$. Only begonia, coleus, fuchsia, petunia, and verbena exhibited a significant reduction in height at $9.8 \mathrm{dS} \cdot \mathrm{m}^{-1}$ EC as compared with $4.0 \mathrm{dS} \cdot \mathrm{m}^{-1}$; in this regard, height was the least affected parameter. As EC increased from 12.1 to $14.2 \mathrm{dS} \cdot \mathrm{m}^{-1}$ only zinnia, snapdragon, petunia, pansy, and coleus exhibited further damage (Figs. 2 and 4-6).

A classification of the 14 species would be useful to growers to provide them some guidance as to which species could be irrigated with more saline water while not compromising plant growth and quality to large degree.
We developed a classification based on visual inspection of the data on percent reduction in DW at the $4.0-\mathrm{dS} \cdot \mathrm{m}^{-1} \mathrm{vs}$. $14.2-\mathrm{dS} \cdot \mathrm{m}^{-1}$ treatments and this correlates to four clusters we noted from Table 1. Photographs at harvest taken from one species representative of each of the four groups are presented (Fig. 7).

\section{Discussion}

Plant drought stress and saline stress effects are similar during early onset of stress. The rapid reduction in 

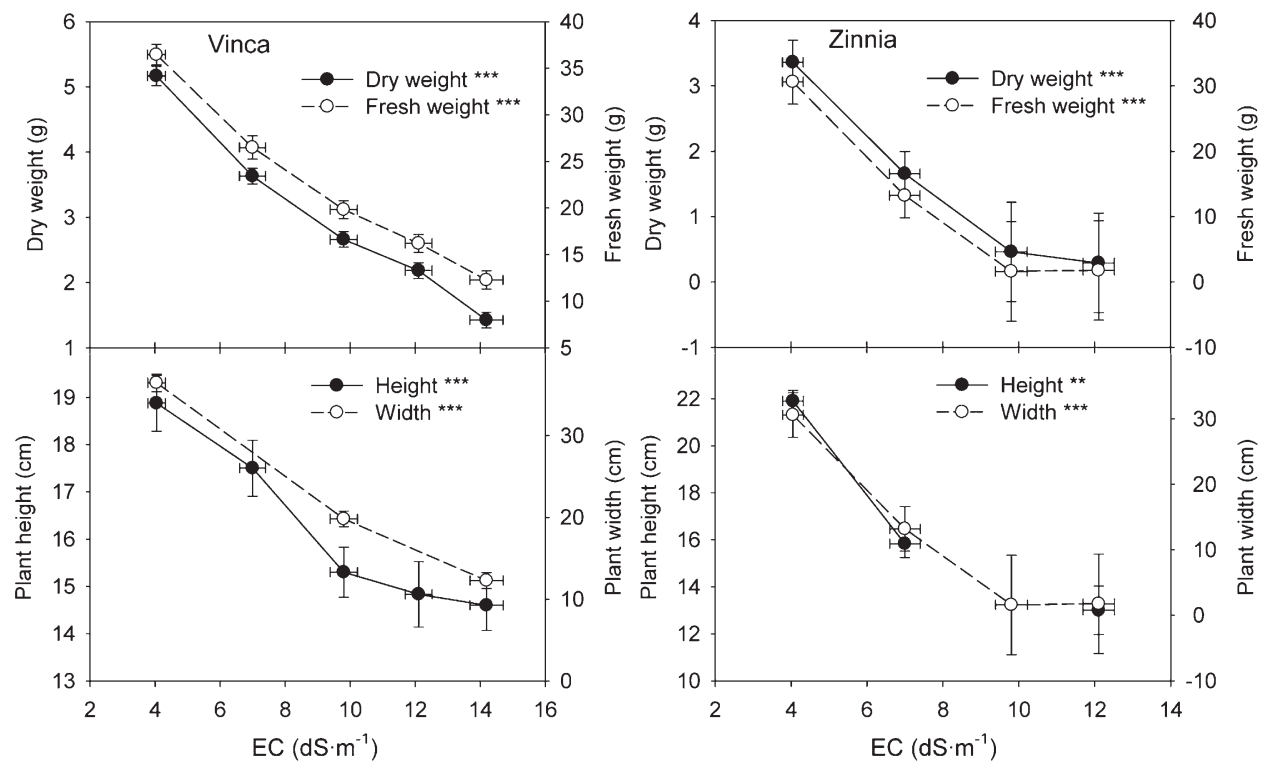

Fig. 6. Growth response of vinca and zinnia transplants to increasing root-zone salinity following a 5-week treatment period; $y$ data are means \pm SE of five plants; $x$ data are means \pm SE of weekly pour-thru electrical conductivity $(\mathrm{EC})$ measurements; $^{1} \mathrm{dS} \cdot \mathrm{m}^{-1}=1$ $\mathrm{mmho} / \mathrm{cm}, 1 \mathrm{~g}=0.0353 \mathrm{oz}, 1 \mathrm{~cm}=0.3937 \mathrm{inch} ; \mathrm{NS},{ }^{*},{ }^{*}{ }^{*}{ }^{* *}$, nonsignificant or significant at $P \leq 0.05,0.01,0.001$, respectively.

Table 1. Classification of 14 bedding plant species based on tolerance to extremely saline substrate; average electrical conductivity (EC) $14.2 \mathrm{dS} \cdot \mathrm{m}^{-1}$ $\left(1 \mathrm{dS} \cdot \mathrm{m}^{-1}=1 \mathrm{mmho} / \mathrm{cm}\right)$ during the 5 -week treatment period in the greenhouse.

\begin{tabular}{|c|c|c|}
\hline & Species & $\begin{array}{l}\text { Dry wt }(\mathrm{DW}) \text { reduction with } \\
14.2 \mathrm{dS} \cdot \mathrm{m}^{-1} \mathrm{EC} \text { as compared } \\
\text { with control }\left(4.0 \mathrm{dS} \cdot \mathrm{m}^{-1}\right)\end{array}$ \\
\hline Most tolerant & snapdragon ad petunia & DW reduced $\geq 50 \%$ and $<70 \%$ \\
\hline $\begin{array}{c}\text { Somewhat } \\
\text { tolerant }\end{array}$ & $\begin{array}{l}\text { begonia, fuchsia, coleus, marigold, } \\
\text { vinca, verbena, and geranium }\end{array}$ & DW reduced $\geq 70 \%$ and $<90 \%$ \\
\hline $\begin{array}{l}\text { Moderately } \\
\text { sensitive }\end{array}$ & impatiens, euphorbia, and salvina & DW reduced by $\geq 90 \%$ \\
\hline $\begin{array}{l}\text { Extremely } \\
\text { sensitive }\end{array}$ & zinnia and pansy & $\begin{array}{l}100 \% \text { mortality at } \\
14.2 \mathrm{dS} \cdot \mathrm{m}^{-1} \mathrm{EC}\end{array}$ \\
\hline
\end{tabular}

growth occurring across seconds or minutes is mainly due to changes in cell water relationships and not due to toxic amounts of salt ions in cells (Munns, 2002). When plants are exposed to high levels of salt over an extended period (days to weeks), salt stress injury may be visible as chlorosis (yellowing) or death of older leaves (de Lacerda et al., 2003). Salt injury at this stage is due to ion accumulation, mainly, in older transpiring leaves. The rate of ion accumulation in older leaves is greater than the capability of the vacuole to compartmentalize them; hence, they build up in the cytoplasm inhibiting enzyme activity or build up in cell walls dehydrating them (Munns, 2002). Salinity reduces growth in plants; this reduction in growth may result from salt effects on physiological processes, biochemical reactions, or a combination of such factors (Seemann and Critchley, 1985).

Because of the high value of both ornamentals and floriculture species, it is imperative to determine the salt tolerance of popular bedding plants during greenhouse production. Our results can be used by greenhouse operations to select plants suitable for their water's salinity.

A similar experiment was carried out in containerized plants growing in soil-less substrate in two greenhouses in Texas by Niu and Rodriguez (2006) with five landscape herbaceous perennials. Yarrow (Achillea millefolium), agastache (Agastache cana), coneflower (Echinacea purpurea), gaillardia (Gaillardia aristata), and scarlet sage (Salvia coccinea) were grown with irrigation water amended with salts to achieve $4.0,7.0$, or $9.8 \mathrm{dS} \cdot \mathrm{m}^{-1}$ EC. In the summer experiment, shoot DW of yarrow, agastache, and gaillardia were significantly less at 7.0 or 9.8 $\mathrm{dS} \cdot \mathrm{m}^{-1} \mathrm{EC}$ as compared with the control $\left(4.0 \mathrm{dS} \cdot \mathrm{m}^{-1}\right)$. In the fall experiment, shoot DW of yarrow and gaillardia were reduced at 7.0 and $9.8 \mathrm{dS} \cdot \mathrm{m}^{-1} \mathrm{EC}$ as compared with the control, whereas that of agastache, cone-flower, and scarlet sage were similar among the treatments (Niu and Rodriguez, 2006). Therefore, environmental conditions such as temperature and irradiance affected salt tolerance of yarrow, gaillardia, and agastache. However, the relative salt tolerance among their tested species was generally consistent. Yarrow, gaillardia, and scarlet sage had relatively high salt tolerance; at 9.8 $\mathrm{dS} \cdot \mathrm{m}^{-1} \mathrm{EC}$, they were about $30 \%$ smaller in height than the control. They could be irrigated with saline solution up to $9.8 \mathrm{dS} \cdot \mathrm{m}^{-1} \mathrm{EC}$ under both summer and fall condition in the greenhouse with acceptable performance. Agastache and coneflower were sensitive and should not be irrigated with water $\geq 7.0 \mathrm{dS} \cdot \mathrm{m}^{-1}$ EC (Niu and Rodriguez, 2006).

Within a given genus, species can vary in their salt tolerance. For example, Morgan and Reed (1998) found for new guinea impatiens (Impatiens hawkeri) shoot FW was reduced by $75 \%$ as salinity increased from 0 to 14 


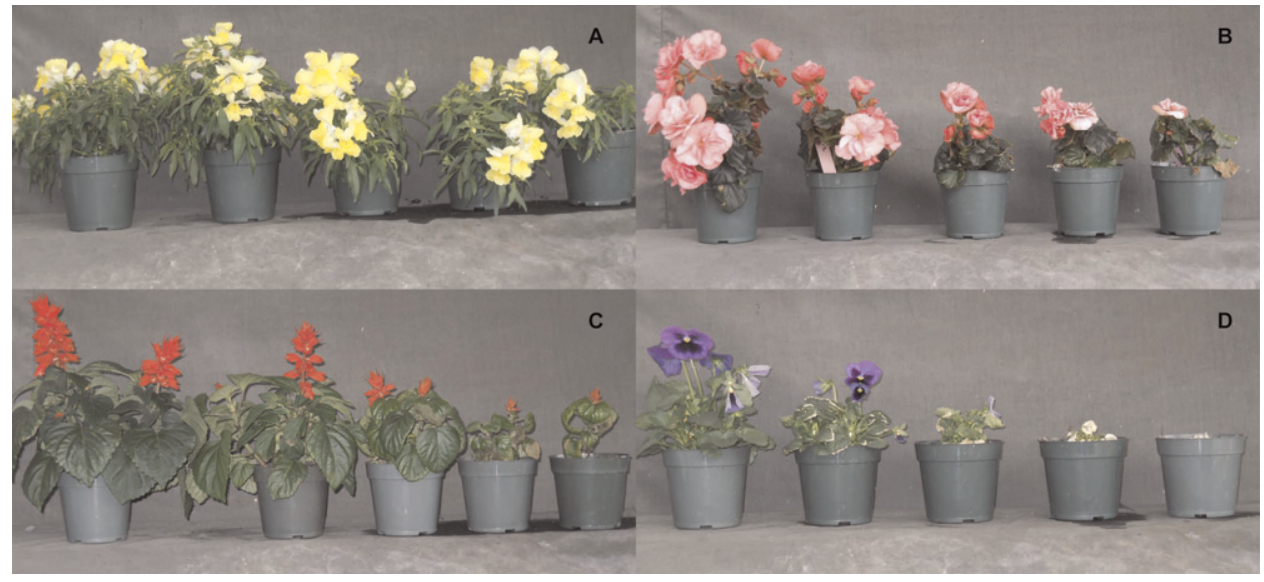

Fig. 7. Species representative of the four salt-tolerance groups: (A) snapdragon (most tolerant), (B) begonia (somewhat tolerant), (C) salvia (moderately sensitive), and (D) pansy (extremely sensitive). Within each panel, from left to right plants were grown for 5 weeks with average pour-thru substrate electrical conductivity (EC) 4.0 (control), 7.0, 9.8, 12.1, or 14.2 dS· $\mathrm{m}^{-1}$; $1 \mathrm{dS} \cdot \mathrm{m}^{-1}=1 \mathrm{mmho} / \mathrm{cm}$.

$\mathrm{mol} \cdot \mathrm{m}^{-3}(14 \mathrm{~mm} \mathrm{NaCl})$ against their control. In our experiment, FW of the related impatiens species (I. walleriana) was reduced by only $21 \%$ as salinity comparing our $20 \mathrm{~mm} \mathrm{NaCl}$ treatment $\left(7.0 \mathrm{dS} \cdot \mathrm{m}^{-1} \mathrm{EC}\right)$ to control plants.

We classified bedding plant species on the basis of growth response to increasing $\mathrm{NaCl}$ salinity in the irrigation water for a 5 -week treatment period. It would be interesting to further research the impact of duration of saline exposure on growth reduction. For example, Sonneveld and Voogt (1983) carried out a similar greenhouse experiment on five cut flower species screening for reduction in flower stem yield but across a 1 - to 2 -year treatment period and using much lower concentrations of salt in the irrigation water (EC 0.2 to 3.0 $\left.\mathrm{dS} \cdot \mathrm{m}^{-1}\right)$. Carnation (Dianthus caryophyllus) and chrysanthemum (Chrysanthemum morifolium) proved to be the least sensitive to $\mathrm{NaCl}$; cut flower yield was reduced by only $6.9 \%$ when exposed to $9.8 \mathrm{dS} \cdot \mathrm{m}^{-1} \mathrm{EC}$ through irrigation water. Gerbera (Gerbera jamesonii) and hippeastrum (Hippeastrum vittatum) were moderately sensitive to salt exhibiting a yield reduction of $12 \%$ and $18 \%$, as salinity increased from 4.0 to 9.8 $\mathrm{dS} \cdot \mathrm{m}^{-1} \mathrm{EC}$, respectively. Anthurium (Anthurium andreanum) was the most sensitive, exhibiting a $22 \%$ reduction in yield of cut flowers as salt increased from 4.0 to $9.8 \mathrm{dS} \cdot \mathrm{m}^{-1} \mathrm{EC}$.

Tija and Rose (1987) classified 45 horticulture bedding plants in an area on the beach front where they were exposed to salt spray and also irrigated with well water with high salt content. Of those species, 11 overlapped with the 14 species we studied. Our findings were relatively similar for the species studied: pansy did poorly; marigold, geranium, vinca, verbena, and begonia were moderately tolerant; and petunia was quite tolerant. Some differences in results were found: impatiens and salvia (moderately sensitive in our experiment and fairly resistant in theirs); and coleus (moderately tolerant in our experiment and sensitive in theirs). The differences between our studies may stem from the fact that we grew plants in highly controlled environment in greenhouse vs. in a landscape with salt spray. Further, the specific cultivars used in the two experiments were different.

Zollinger et al. (2007) measured weekly visual quality and gas exchange and final shoot and root DWs of four intermountain western U.S. native ornamental herbaceous perennials [balloon flower (Penstemon palmeri), colorado four o'clock (Mirabilis multiflora), sticky geranium (Geranium viscosissimum), antelope sage (Eriogonum jamesii)] and four common ornamental herbaceous perennials [cone-flower (E. purpurea), common lavender (Lavandula angustifolia), 'Alaska' shasta daisy (Leucanthemum superbum), 'Red Rocks' beardtongue (Penstemon mexicali)] irrigated with a solution containing two calcium chloride $\left(\mathrm{CaCl}_{2}\right): 1 \mathrm{NaCl}(\mathrm{M}$ ratio $)$ at salinity levels of 0 (control), 1000, 3000, and $5000 \mathrm{mg} \cdot \mathrm{L}^{-1}$ during two 8-week experiments. The authors reported that response of visual quality to salts was inconsistent with dry matter response. While we did not specifically rate visual features of our plants, we did find some correlation between growth reduction and visual quality. Pansy and zinnia were the most sensitive species to salt (in terms of mortality and DW reduction), both of these species exhibited severe leaf marginal necrosis at our lowest treatment of added salt $\left(7.0 \mathrm{dS} \cdot \mathrm{m}^{-1}\right)$, whereas snapdragon was the least sensitive species in terms of DW response and leaf visual quality was unaffected up to $14.2 \mathrm{dS} \cdot \mathrm{m}^{-1}$ (Fig. 7).

Salt pretreatment/acclimation led to enhanced performance (reducing leaf necrosis) of potato (Solanum tubersoum) growing in a hydroponic system and exposed to 150-180 mM $\mathrm{NaCl}$ and $\mathrm{CaCl}_{2}$ for 2 weeks. Preacclimated plants were exposed to increasing salt concentrations for the 3 weeks preceding the experimental period. The most affected cultivar (9506) exhibited roughly 55\% leaf necrosis following the 2 -week treatment period when not preacclimated to salts (control). When preacclimated with either $\mathrm{NaCl}$ or $\mathrm{CaCl}_{2}$, plants exhibited about 30\% leaf necrosis (Etehadnia et al., 2010). Floriculture species might also respond to preacclimation, allowing them to subsequently be grown under higher salinity conditions.

\section{Conclusions}

Overall our experimental results suggest that some bedding plant species can be grown in moderately saline irrigation water. If a grower has access to only saline water they could use it on crops such as snapdragon, petunia, 
verbena, and geranium and still have fairly high plant growth, whereas other species will demand high-quality water or high leaching fractions to have a successful production. Sensitive plants in our experiment included zinnia, pansy, impatiens, euphorbia, and salvia. For the rest of the species, we screened moderately saline water might be applied, perhaps $\leq 7 \cdot \mathrm{dS} \cdot \mathrm{m}^{-1} \mathrm{EC}$; a slight growth reduction will be found but plants should still be visually acceptable in the market.

\section{Literature cited}

Cavins, T.J., B.E. Whipker, W.C. Fonteno, B. Harden, I. McCall, and J.L. Gibson. 2000. Monitoring and Managing $\mathrm{pH}$ and EC Using the PourThru Extraction Method. North Carolina State Univ., Hort. Info. Lflt. 590. <http://www.ces.ncsu.edu/depts/ hort/floriculture/hils/HIL590.pdf >.

de Lacerda, C.F., J. Cabraia, M.A. Oliva, H.A. Ruiz, and J.T. Prisco. 2003. Solute accumulation and distribution during shoot and leaf development in two sorghum genotypes under salt stress. Environ. Expt. Bot. 49:107-120.

Etehadnia, M., J. Schoenau, D. Waterer, and T. Karen. 2010. The effect of $\mathrm{CaCl} 2$ and $\mathrm{NaCl}$ salt acclimation in stress tolerance and its potential role in ABA and scion/ rootstock-mediated salt stress responses. Plant Stress 4:72-81.

Lerner, R. 2006. Roadside de-icing salts and ornamental plants. Dept. of Horticulture Purdue Univ. Coop. Ext. Serv., West Lafayette, IN.

Lieth, J.H. and D.W. Burger. 1989 Growth of chrysanthemum using an irrigation system controlled by soil moisture tension. J. Amer. Soc. Hort. Sci. 114: 387-392.

Morgan, K.T., T.A. Wheaton, L.R. Parsons, and W.S. Castle. 2008. Effects of reclaimed municipal water on horticultural characteristics, fruit quality, and soil and leaf mineral concentration of citrus. HortScience 43:459-464.

Morgan, T. and D. Reed. 1998. Characterizing salinity limits of new guinea impatiens in recirculating subirrigation. J. Amer. Soc. Hort. Sci. 123:156-160.

Munns, R. 2002. Comparative physiology of salt and water stress. Plant Cell Environ. 25:239-250.

Niu, G. and D. Rodriguez. 2006. Relative salt tolerance of five herbaceous perennials. HortScience 41:1493-1497.
Seemann, J. and C. Critchley. 1985. Effects of salt stress on the growth, ion content, stomatal behaviour and photosynthetic capacity of a salt-sensitive species, Phaseolus vulgaris L. Planta 164: 151-162.

Skaggs, H., P. Poss, J. Shouse, and M. Grieve. 2006. Irrigating forage crops with saline waters: 1. Volumetric lysimeter studies. Soil Sci. Soc. Amer. J. 5:815-823.

Sonneveld, C. and W. Voogt. 1983. Studies on the salt tolerance of some flower crops grown under glass. Plant Soil $74: 41-52$.

Tija, B. and S.A. Rose. 1987. Salt tolerant bedding plants. Proc. Florida State Hort. Soc. 100:181-182.

$\mathrm{Xu}, \mathrm{K}$., P. Hong, L. Luo, and T. Xia. 2009. Overexpression of AtNHXl, a vacuolar $\mathrm{Na}^{+} / \mathrm{H}^{+}$antiporter from Arabidopsis thalina, in Petunia bybrida enhances salt and drought tolerance. J. Plant Biol. 52: 453-461.

Zollinger, N., R. Koenig, T. Cerny-Koenig, and R. Kjelgren. 2007. Relative salinity tolerance of intermountain western United States native herbaceous perennials. HortScience 42:529-534. 